Stereotactic

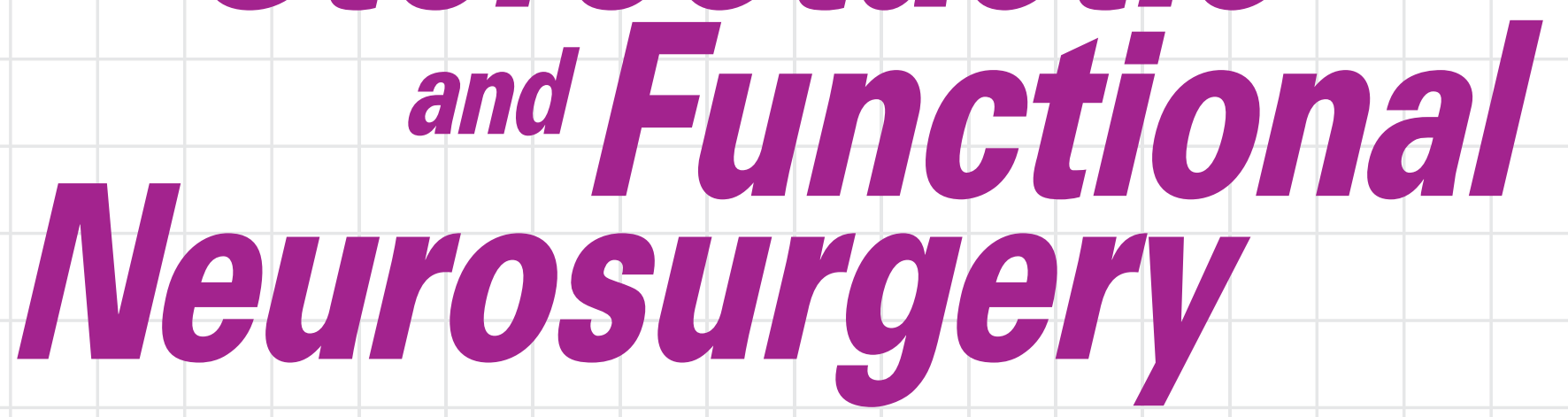

S. Karger
Medical and Scientific Publishers Basel $\cdot$ Freiburg - Paris .
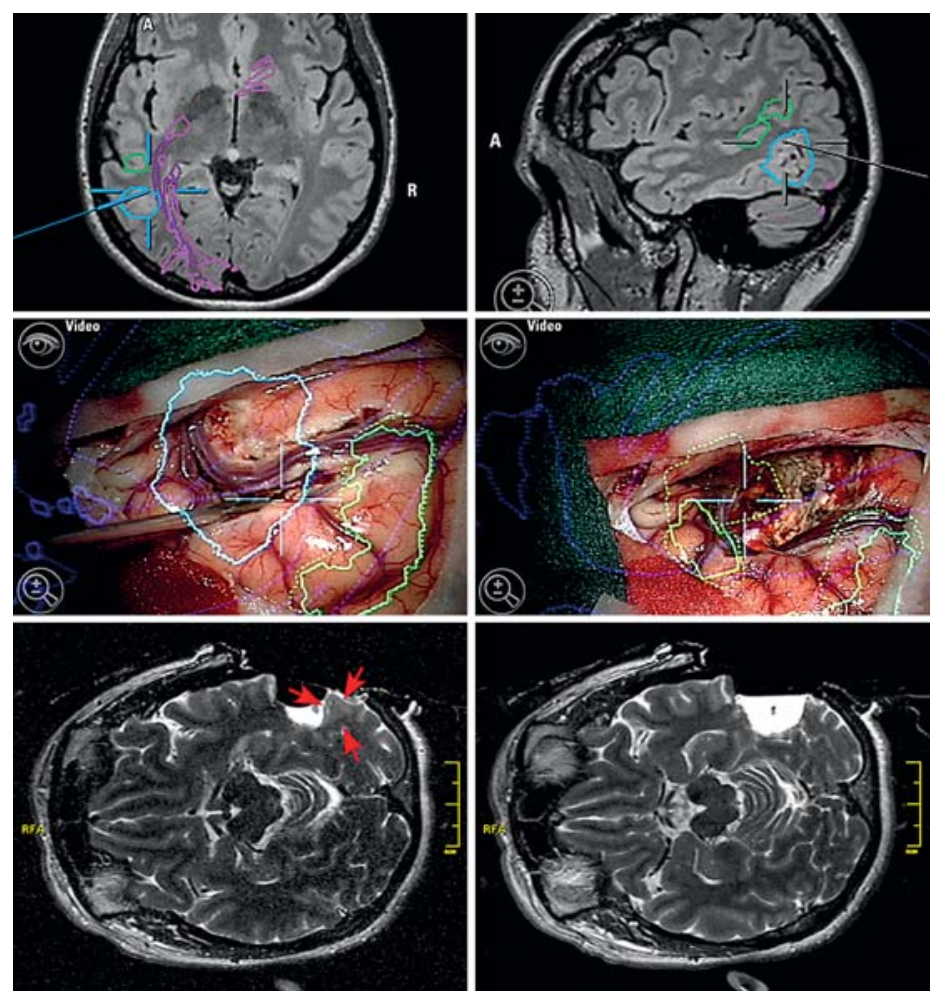

London - New York · Chennai -

New Delhi · Bangkok · Beijing ·

Shanghai - Tokyo - Kuala Lumpur

Singapore - Sydney 


\section{Rediscover Vesalius}

The medical revolution of the 16th century brought to life for the 21st century



KARGER

Medical \& Scientific

Publishers

\section{ANDREAS VESALIUS}

\section{The Fabric \\ of the Human Body}

\section{An Annotated Translation of the 1543 and 1555 Editions of}

"De Humani Corporis Fabrica" by

\section{DANIEL H. GARRISON \\ MALCOLM H. HAST}

with contributions by Vivian Nutton and Nancy Siraisi

For the first time ever, both editions of Andreas Vesalius' masterpiece "De Humani Corporis Fabrica" are accessible in the English language. They were critically compared and published in a modern layout transforming the Renaissance anatomical atlas for the 21st-century reader. More than 5,000 annotations cover anything from antique sources over Galenic references to the medical and cultural background of Vesalius' time. Also included are Vesalius' handwritten notes for a never published third edition.

To enable the reader and medical student to really study Vesalius' woodcut illustrations, the images were digitally enhanced and often enlarged to feature his painstaking work of marking each pertinent anatomical part with characters. All over Vesalius' descriptive text, the standard Latin Nomina Anatomica and Terminologia Anatomica provide the reader with the modern medical terminology.

Vesalius, A., The Fabric of the Human Body

An Annotated Translation of the 1543 and 1555 Editions of

"De Humani Corporis Fabrica Libri Septem" by

D.H. Garrison and M.H. Hast

CXX + 1338 p., 340 fig., in two volumes, hard cover, with slip case, 2014

$315 \times 435 \mathrm{~mm} / 12 \times 17^{\prime \prime}, 16 \mathrm{~kg} / 35 \mathrm{lbs}$

CHF 1,500.- / EUR 1,250.- / USD 1,650.00

ISBN 978-3-318-02246-9

\section{www.karger.com}

Postage and handling included

VAT \& import taxes excluded, no right to return

Prices subject to change, EUR price for Germany,

USD price for USA and Latin America only




Official Journal of

\begin{tabular}{ll} 
World Society for \\
$\begin{array}{l}\text { Stereotactic and } \\
\text { Functional Neurosurgery }\end{array}$ \\
$\begin{array}{ll}\text { American Society for } \\
\text { Stereotactic and } \\
\text { Functional Neurosurgery }\end{array}$ \\
\hline
\end{tabular}

Editor

David W. Roberts, Lebanon, N.H.

\section{Associate Editor}

Philip L. Gildenberg, Houston, Tex.

\section{Assistant Editor}

Melissa D. Robb, Lebanon, N.H.

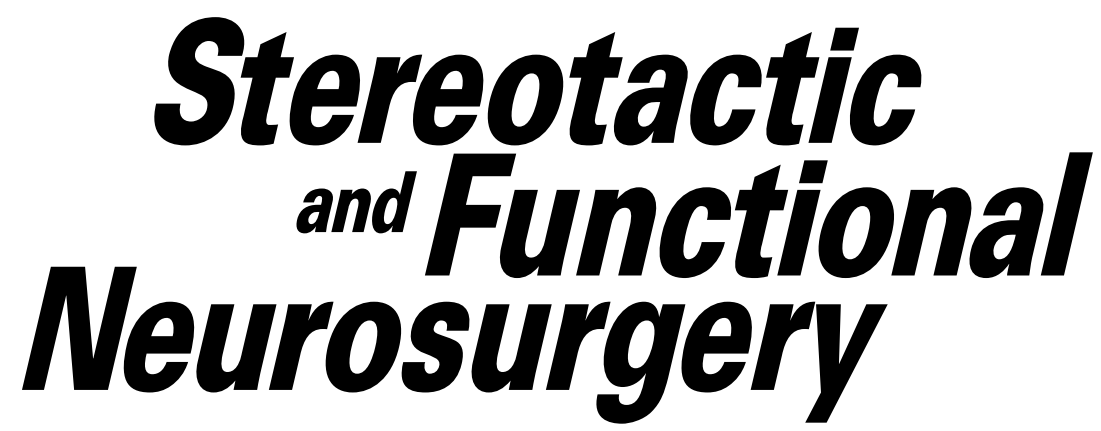

Founded 1938 as 'Confinia Neurologica' by E.A. Spiegel

Continued 1975-1988 as 'Applied Neurophysiology'

\section{Editorial Board}

A. Abosch, Aurora, Colo.

M.L.J. Apuzzo, Los Angeles, Calif.

T. Aziz, Oxford

N.M. Barbaro, Indianapolis, Ind.

A.L. Benabid, Grenoble

G. Broggi, Milan

B.P. Brophy, Adelaide

K.J. Burchiel, Portland, Oreg.

J.W. Chang, Seoul

G.R. Cosgrove, Providence, R.I.

W.A. Friedman, Gainesville, Fla.

R.E. Gross, Atlanta, Ga.

T. Hori, Tokyo

M.G. Kaplitt, New York, N.Y.

Y. Katayama, Tokyo

P.J. Kelly, New York, N.Y.
D.S. Kondziolka, New York, N.Y.

J.K. Krauss, Hannover

K.H. Lee, Rochester, Minn.

A. Lozano, Toronto, Ont.

L.D. Lunsford, Pittsburgh, Pa.

F. Piedimonte, Buenos Aires

V. Rajshekhar, Vellore

J. Regis, Marseille

A.R. Rezai, Columbus, Ohio

M. Schulder, Manhassett, N.Y.

M.P. Sindou, Lyon

K.V. Slavin, Chicago, Ill.

T. Taira, Tokyo

Z. Tian, Beijing

F. Velasco Campos, Mexico City

O. Vilela Filho, Goiânia 


\section{Stereotactic and Functional Neurosurgery}

\section{Submission}

Only original papers written in English are considered and should be submitted using the online submission website at:

\section{www.karger.com/sfn}

Should you experience any problems with your submission, please contact:

sfn@karger.com
Professor David W. Roberts
Section of Neurosurgery
Dartmouth Medical Center
1, Medical Center Drive
Lebanon, NH 03756-0001 (USA)
Tel. +1 $6036508734 / 6$
Fax +16036507911

\section{Conditions}

All manuscripts are subject to editorial review. Manuscripts are received with the explicit understanding that they are not under simultaneous consideration by any other publication. Submission of an article for publication implies the transfer of the copyright from the author to the publisher upon acceptance. Accepted papers become the permanent property of Stereotactic and Functional Neurosurgery and may not be reproduced by any means, in whole or in part, without the written consent of the publisher. It is the author's responsibility to obtain permission to reproduce illustrations, tables, etc. from other publications.

\section{Arrangement}

Title page: The first page of each paper should indicate the title, the authors' names, the institute where the work was conducted, and a short title for use as running head.

Full address: The exact postal address of the corresponding author complete with postal code must be given at the bottom of the title page. Please also supply phone and fax numbers, as well as e-mail address.

Key words: Please supply 3-10 key words in English that reflect the content of the paper.

Abstract: Each paper needs an abstract of up to 200 words. It should be structured as follows:

Background: What is the major motive that prompted the study?

Objectives: What is the purpose of the study?

Methods: How was the study done?

Results: $\quad$ Most important findings

Conclusions: Most important conclusions

Footnotes: Avoid footnotes.

Tables and illustrations: Tables and illustrations (both numbered in Arabic numerals) should be prepared on separate pages. Tables require a heading and figures a legend, also prepared on a separate page. For the reproduction of illustrations, only good drawings and original photographs can be accepted; negatives or photocopies cannot be used. Due to technical reasons, figures with a screen background should not be submitted. When possible, group several illustrations in one block for reproduction (max. size $180 \times 223 \mathrm{~mm}$ ) or provide crop marks. Electronically submitted $b / w$ half-tone and color illustrations must have a final resolution of 300 dpi after scaling, line drawings one of 800-1,200 dpi.

\section{Color Illustrations}

Online edition: Color illustrations are reproduced free of charge. In the print version, the illustrations are reproduced in black and white. Please avoid referring to the colors in the text and figure legends.

Print edition: Up to 6 color illustrations per page can be integrated within the text at CHF 800.- per page.

\section{References}

In the text identify references by Arabic numerals [in square brackets]. Material submitted for publication but not yet accepted should be noted as [unpublished data] and not be included in the reference list. The list of references should include only those publications which are cited in the text. Do not alphabetize; number references in the order in which they are first mentioned in the text. The surnames of the authors followed by initials should be given. There should be no punctuation other than a comma to separate the authors. Preferably, please cite all authors. Abbreviate journal names according to the Index Medicus system. Also see International Committee of Medical Journal Editors: Uniform requirements for manuscripts submitted to biomedical journals (www.icmje.org).

\section{Examples}

(a) Papers published in periodicals: Chatel J-M, Bernard $\mathrm{H}$, Orson FM: Isolation and characterization of two complete Ara h 2 isoforms cDNA. Int Arch Allergy Immunol 2003;131:14-18

(b) Papers published only with DOI numbers:

Theoharides TC, Boucher W, Spear K: Serum interleukin-6 reflects disease severity and osteoporosis in mastocytosis patients. Int Arch Allergy Immunol DOI: $10.1159 / 000063858$

(c) Monographs: Matthews DE, Farewell VT: Using and Understanding Medical Statistics, ed 3, revised. Basel, Karger, 1996

(d) Edited books: DuBois RN: Cyclooxygenase-2 and colorectal cancer; in Dannenberg AJ, Dubois RN (eds): COX-2. Prog Exp Tum Res. Basel, Karger, 2003, vol 37, pp 124-137.

Reference Management Software: Use of EndNote is recommended for easy management and formatting of citations and reference lists.

\section{Digital Object Identifier (DOI)}

S. Karger Publishers supports DOIs as unique identifiers for articles. A DOI number will be printed on the title page of each article. DOIs can be useful in the future for identifying and citing articles published online without volume or issue information. More information can be found at www.doi.org.

\section{Supplementary Material}

Supplementary material is restricted to additional data that are not necessary for the scientific integrity and conclusions of the paper. Please note that all supplementary files will undergo editorial review and should be submitted together with the original manuscript. The Editors reserve the right to limit the scope and length of the supplementary material. Supplementary material must meet production quality standards for Web publication without the need for any modification or editing. In general, supplementary files should not exceed $10 \mathrm{Mb}$ in size. All figures and tables should have titles and legends and all files should be supplied separately and named clearly. Acceptable files and formats are: Word or PDF files, Excel spreadsheets (only if the data cannot be converted properly to a PDF file), and video files (.mov, .avi, .mpeg).

\section{Author's Choice ${ }^{\mathrm{TM}}$}

Karger's Author's Choice ${ }^{\mathrm{TM}}$ service broadens the reach of your article and gives all users worldwide free and full access for reading, downloading and printing at www.karger.com. The option is available for a onetime fee of CHF 3,000.-, which is a permissible cost in grant allocation. More information can be found at www.karger.com/authors choice.

\section{NIH-Funded Research}

The U.S. National Institutes of Health (NIH) mandates under the NIH Public Access Policy that final, peerreviewed manuscripts appear in its digital database within 12 months of the official publication date. As a service to authors, Karger submits the final version of your article on your behalf to PubMed Central. For those selecting our premium Author's Choice ${ }^{\mathrm{TM}}$ service, the usual embargo will be overriden, accelerating the accessibility of your work. More details on NIH's Public Access Policy are available at http://publicaccess. nih.gov/policy.htm.

\section{Self-Archiving}

Karger permits authors to archive their pre-prints (i.e. pre-refereeing) or post-prints (i.e. final draft post-refereeing) on their personal or institution's servers, provided the following conditions are met: Articles may not be used for commercial purposes, must be linked to the publisher's version, and must acknowledge the publisher's copyright. Authors selecting Karger's Author's Choice ${ }^{\mathrm{TM}}$ feature, however, are also permitted to archive the final, published version of their article, which includes copyediting and design improvements as well as citation links.

\section{Page Charges}

There are no page charges for papers of 5 or fewer printed pages (including tables, illustrations and references). Each additional complete or partial page is charged to the author at CHF 325.-. The allotted size of a paper is equal to approx. 16 double-spaced manuscript pages (including tables, illustrations and references).

\section{Proofs}

Unless indicated otherwise, proofs are sent to the corresponding author and should be returned with the least possible delay. Alterations other than the correction of printer's errors are charged to the author.

\section{Reprints}

Order forms and a price list are sent with the proofs. Orders submitted after the issue is printed are subject to considerably higher prices.

\section{KARGER}

E-Mail karger@karger.com www.karger.com
(C) 2014 S. Karger AG, Basel 


\section{Stereotactic and Functional Neurosurgery}

ISSN Print Edition: 1011-6125 ISSN Online Edition: 1423-0372

Journal Homepage: www.karger.com/sfn

Publication Data: Stereotactic and Functional Neurosurgery is published 6 times a year. Volume 92 with 6 issues appears in 2014

Copyright: (c) 2014 S. Karger AG, Basel (Switzerland). All rights reserved. No part of this publication may be translated into other languages, reproduced or utilized in any form or by any means, electronic or mechanical including photocopying, recording, microcopying, or by any information storage and retrieval system, without permission in writing from the publisher or, in the case of photocopying, direct payment of a specified fee to the Copyright Clearance Center.

Disclaimer: The statements, opinions and data contained in this publication are solely those of the individual authors and contributors and not of the publisher and the editor(s). The appearance of advertisements in the journal is not a warranty, endorsement, or approval of the products or services advertised or of their effectiveness, quality or safety. The publisher and the editor(s) disclaim responsibility for any injury to persons or property resulting from any ideas, methods instructions or products referred to in the content or advertisements.
Subscription Rates: Subscriptions run for a full calendar year. Prices are given per year. Personal subscription:

Print or Online

CHF 978.-

EUR 802--

USD 978.00

Print+Online combined CHF 1026.-

EUR 841.-

USD 1026.00

postage and handling (added to print and print+online)

CHF 44.40 Europe, CHF 64.80 Overseas

EUR 36.00

USD 58.80

Institutional subscription:

Print or Online

Print+Online combined

CHF 1956.-

EUR 1603.-

CHF 2152.

USD 1956.00

postage and handling (added to print and print+online)

CHF 55.50 Europe, CHF 81.- Overseas

EUR 45.-

USD 73.50

Discount subscription prices:

Societies for Stereotactic and Functional

Neurosurgery are requested to apply for appropriate discounts.
Back Volumes and Single Issues: Information on availability and prices of single print issues and print or electronic back volumes can be obtained from Customer Service atservice@karger.com.

Bibliographic Indices: This journal is regularly listed in bibliographic services, including Current Contents ${ }^{\circledast}$.

Photocopying: This journal has been registered with the Copyright Clearance Center (CCC), as indicated by the code appearing on the first page of each article. For readers in the US, this code signals consent for copying of articles for personal or internal use, or for the personal or internal use of specific clients, provided that the stated fee is paid per copy directly to

Copyright Clearance Center Inc.

222 Rosewood Drive

Danvers, MA 01923 (USA)

A copy of the first page of the article must accompany payment. Consent does not extend to copying for general distribution, for promotion, for creating new works, or for resale. In these cases, specific written permission must be obtained from the copyright owner,

S. Karger AG, P.O. Box

CH-4009 Basel (Switzerland).
Subscription Orders:

Orders can be placed at agencies,

bookstores, directly with the Publisher

\section{S. Karger AG}

Medical and Scientific Publishers

Allschwilerstrasse 10

CH-4009 Basel

Switzerland

t: +41613061111

f: +41613061234

e: karger@karger.com

w: www.karger.com

(for courier services only: Allschwilerstrasse 10

CH-4055 Basel)

or further Karger offices
or representatives:
Germany
S. Karger GmbH
Postfach
79095 Freiburg
Deutschland
(Hausadresse: Wilhelmstrasse 20A,
79098 Freiburg)
t: +49761452070
f: +497614520714
e: information@karger.de
w: www.karger.de
Japan
Karger Japan, Inc.
Shiba Daimon Asahi Bldg. 2F
1-2-23 Shiba Daimon
Minato-ku
Tokyo $105-0012$
Japan
t: +81 364356242
f: +81 364356244
e: publisher@karger.jp
w: www.karger.jp

USA

S. Karger Publishers, Inc

26 West Avon Road

P.O. Box 529

Unionville, CT 06085

Toll free: +18008285479

t: +18606757834

f. +18606757302

e: karger@snet.net

France

Enter \& Read

Albertine Luginbuhl

23, rue du Départ, boite 37

75014 Paris

France

t: $+33(0) 681047685$

e: albertineluginbuhl@orange.fr

South East Asia, China and Taiwan

Karger Regional Office (Malaysia)

Karger Regional Office

Quill 7, 27th Floor

Jalan Stesen Sentral 5

KL Sentral

Kuala Lumpur 50470

Malaysia

t: +60327766803

f: +60327766999

e: service@karger.cn
Karger China

West/5F, China Life Tower

No.16, Chao Wai Street

Chaoyang District

Beijing 100020

China

t: +861058771408

f: +861058771120

e: service@karger.cn; r.chew@karger.cn

w: www.karger.cn

India, Bangladesh, Sri Lanka

Karger India

Plot No. 17, Yusuf Sarai Market

B.L. Glass Building, 2nd Floor

Sri Aurobindo Marg

New Delhi 110016

India

t: +911146029633

f: +911146029634

c: +919891052128

e: r.kumar@kargerindia.com

w: www.karger.com

Change of Address:

Both old and new address should be sent

to the subscription source.

\section{KARGER}

E-Mail karger@karger.com www.karger.com
(C) 2014 S. Karger AG, Basel

The Journal Home Page is available at:

www.karger.com/sfn 


\section{$5^{\text {th }}$ Vienna Symposium on Surgery of Peripheral Nerves Present state of Peripheral Nerve Surgery and New Ideas to Improve the Results}

March 21-23, 2014 • General Hospital Lecture Halls, Vienna, Austria

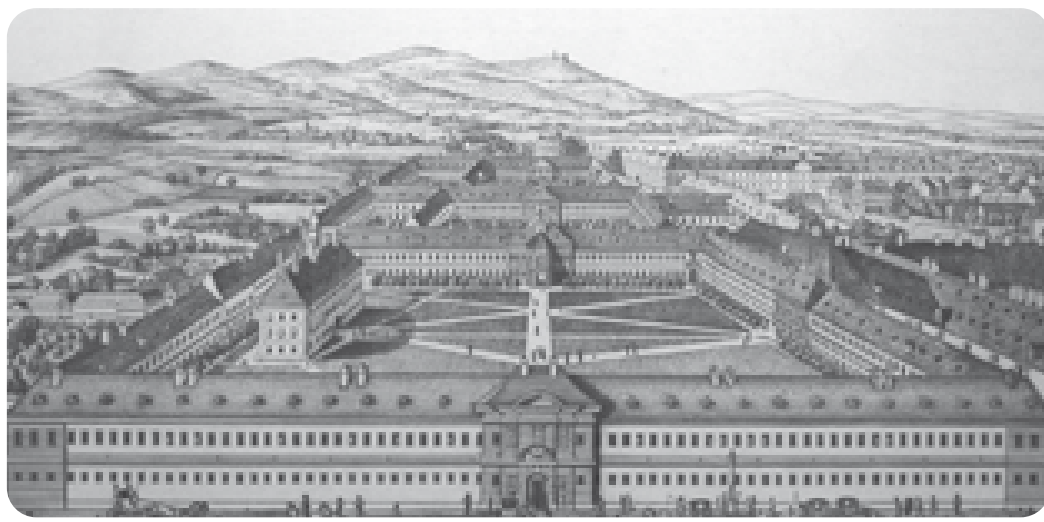

Organizing Committee:

Hanno Millesi

Robert Schmidhammer

David Chiu

Austrian Cluster for Tissue Regeneration

Ludwig Boltzmann Institute for

Traumatology
Hanno Millesi

David Chiu

Stefano Geuna

Tessa Gordon
Pierluigi Tos http://www.medacad.org/pns2014/

\section{Topics:}

- Research,

- Passive motion of tissues in general including peripheral nerves as described since decades and now made visible by high resolution ultrasound,

- Motor Function,

- Muscle Education,

- Surgical technique,

- Pain Syndromes caused by changes located in the peripheral nerves,

- Cerebral Plasticity,

- Traumatic brachial plexus lesion

\section{Congress Office:}

Vienna Medical Academy of

Postgraduate Education \& Research

Catherine Altermann

Alser Strasse 4

A-1090 Vienna, Austria

Phone: (+43/1) 405138318

Fax: $(+43 / 1) 4078274$

E-mail: pns2014@medacad.org

\section{New!}

No. 73 Pubisthed October 2013

Daniel H. Garrison
Vesalius and the Achievement of the Fabrica

Hubert steinke Why Histor Martin Kemp Art and the Science of Appearance art and the science Minds Wide Open: Art Meets interverw wathrastach
For over 40 years the Karger Gazette has been distributed to a growing audience worldwide. Published once a year in newspaper format, it highlights advances in biomedicine and clinical practice, introduces personalities, portrays research institutes and chronicles milestones in the history of Karger Publishers in a lively and readable style. With invited contributions by experts from all over the world, each issue is devoted to a special topic of current interest.

In the latest issue, read free articles on the famous anatomist Andreas Vesalius, his times and his ground-breaking atlas 'De humani corporis fabrica', and more.

For your free print subscription $\rightarrow$ gazette@karger.com Read it online $\rightarrow$ www.karger.com/gazette

\section{KARGER}

S. Karger AG

Medical and Scientific Publishers

Karger Gazette

Allschwilerstrasse 10

CH-4009 Basel

Switzerland

www.karger.com 


\section{Contents}

See the journal website for contents

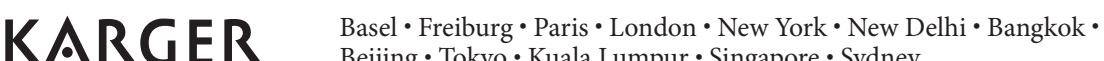
Beijing $\cdot$ Tokyo $\cdot$ Kuala Lumpur $\cdot$ Singapore $\cdot$ Sydney 


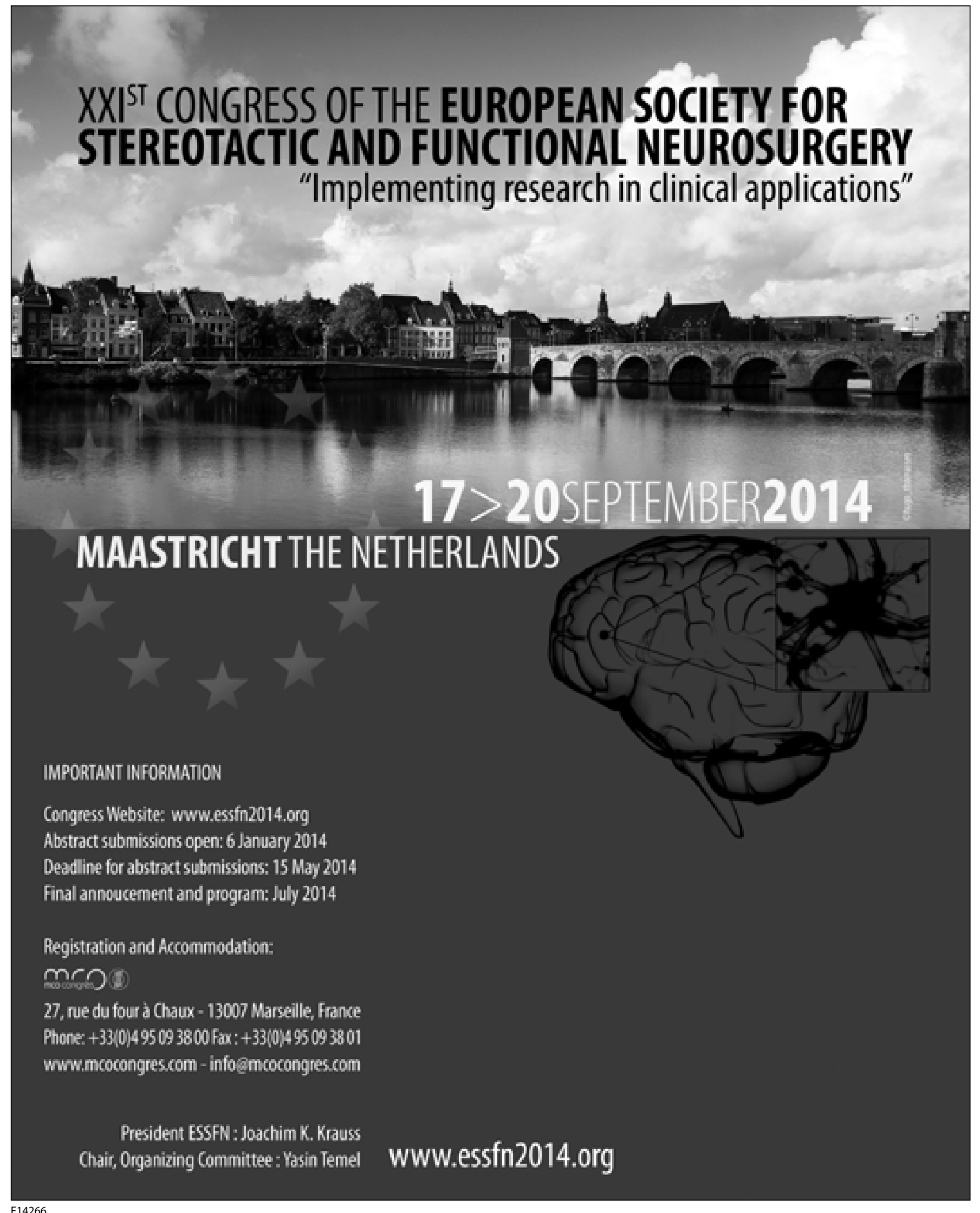




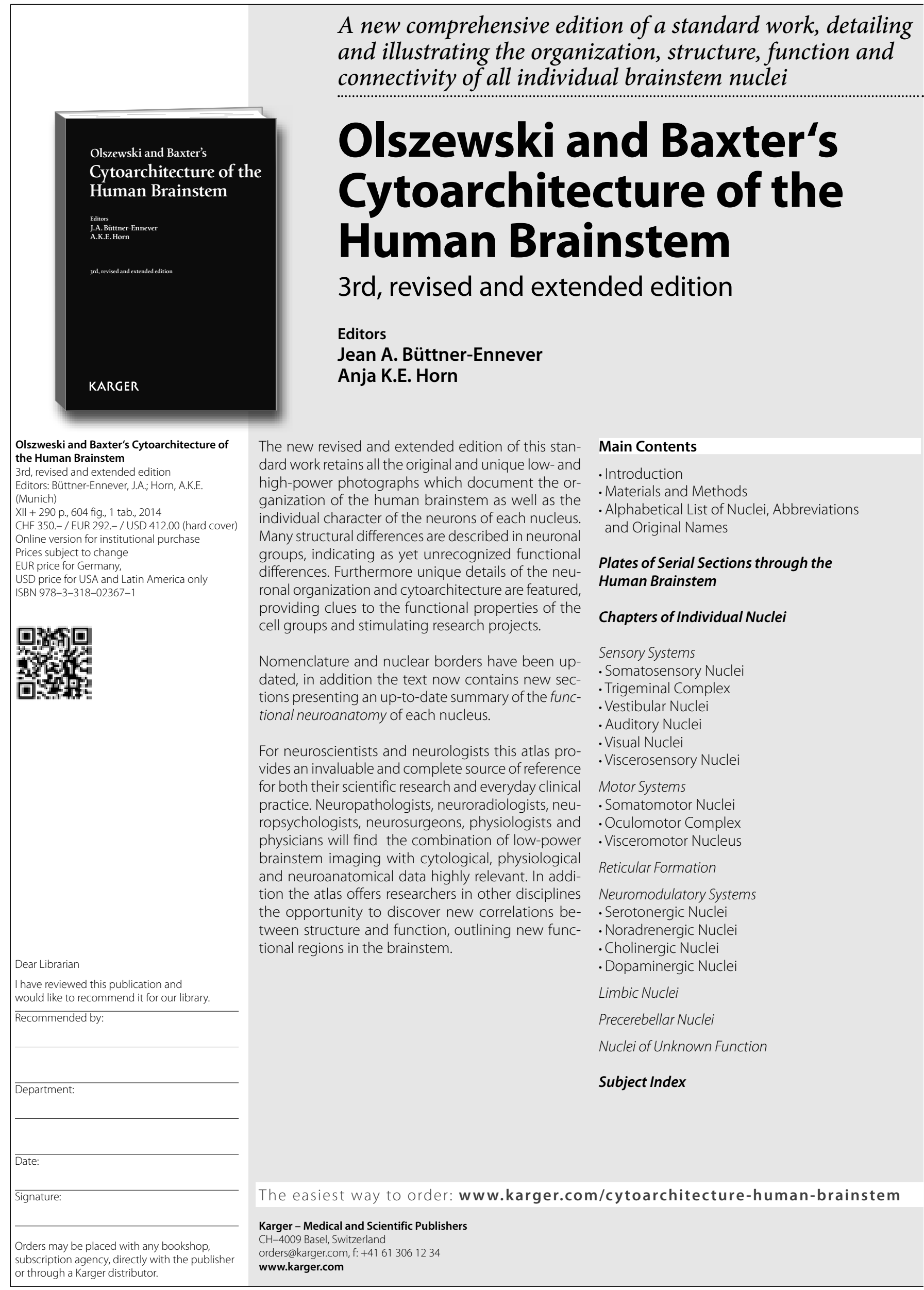




\section{Get complete coverage of clinical research and practice}

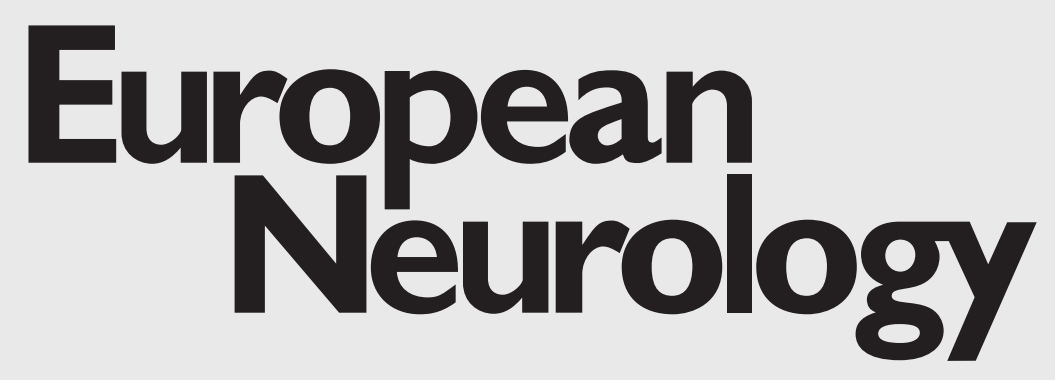

Editor-in-Chief

J. Bogousslavsky, Montreux

More information at

www.karger.com/ene

- Pay-per-View and Subscriber Access to Full Text

- Full Table of Contents

- Full Editorial Board

- Free Abstracts and Selected Articles

- Online Sample Issue

- Submission/Guidelines for Authors

- Subscription Details

- Free Alert Service

- Online Library Recommendation

\section{European Neurology}

2014: Volumes 71, 72

6 issues per volume

Language: English

ISSN 0014-3022 (print)

ISSN 1421-9913 (online)

\section{Selected contributions}

- 'Distorteidolias' - Fantastic Perceptive Distortion. A New, Pure Dorsomedial

Thalamic Syndrome: Delgado, M.G. (Oviedo); Bogousslavsky, J. (Glion)

- A Prospective Study on 132 (ases of Ocular Palsy: Castelluccia, A. (Rome);

Nociti, V. (Milano); Frisullo, G.; Batocchi, A.P. (Rome)

- Progressive Encephalomyelitis with Rigidity and Myoclonus: A Syndrome with Diverse Clinical Features and Antibody Responses: Shugaiv, E. (Istanbul); Leite, M.I. (Oxford); Şehitoğlu, E. (Istanbul); Woodhall, M. (0xford); Çavuş, F. (Istanbul); Waters, P. (Oxford); içöz, S.; Birişisk, Ö.; Uğurel, E.; Ulusoy, C.; Kürtüncü, M.; Vural, B. (Istanbul); Vincent, A. (Oxford); Akman-Demir, G.; Tüzün, E. (Istanbul)

- A New Rechargeable Device for Deep Brain Stimulation: A Prospective Patient Satisfaction Survey: Timmermann, L. (Cologne); Schüpbach, M. (Bern/Paris); Hertel, F. (Idar Oberstein); Wolf, E. (Innsbruck); Eleopra, R. (Udine); Franzini, A.; Servello, D. (Milano); Skogseid, I.-M. (Oslo); Rumia, J. (Barcelona); Aliaga, A.S. (Valencia); Barbe, M.T.;

Pauls, K.A.M. (Cologne); Lin, J.-P. (London); Moro, E. (Toronto, Ont.); Lloyd, A. (0xford); Maarouf, M. (Cologne)

- Neuromelanin Magnetic Resonance Imaging in Parkinson's Disease and Multiple System Atrophy: Matsuura, K.; Maeda, M.; Yata, K.; Ichiba, Y.; Yamaguchi, T.; Kanamaru, K.; Tomimoto, H. (Mie)

- Optimization of Intravenous Immunoglobulin in Chronic Inflammatory Demyelinating Polyneuropathy Evaluated by Grip Strength Measurement: Kokubun, N.; Sada, T. (Tochigi); Yuki, N. (Singapore); Okabe, M.; Hirata, K. (Tochigi)

\section{European Neurology}

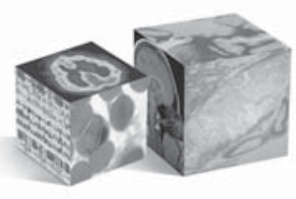

KARGER
European Neurology publishes original papers, reviews and letters to the editor. Papers presented in this journal cover clinical aspects of diseases of the nervous system and muscles, as well as their neuropathological, biochemical, and electrophysiological basis. New diagnostic probes, pharmacological and surgical treatments are evaluated from clinical evidence and basic investigative studies. The journal also features original works and reviews on the history of neurology. 


\section{Stereotactic and Functional Neurosurgery}

Laboratory Investigation

1 A Miniature Optical Neuronavigation System for CT-Guided Stereotaxy

von Jako, C.R. (Wilmington, Mass.); Perlaki, G.; Orsi, G.; Schwarcz, A.; Dóczi, T. (Pécs)

Technical Report

8 Three-Dimensional Accuracy of ECOG Strip Electrode Localization Using Coregistration of Preoperative MRI and Intraoperative Fluoroscopy

Rowland, N.C. (San Francisco, Calif.); Miller, K.J.

(Palo Alto, Calif.); Starr, P.A. (San Francisco, Calif.)

Technology Report

17 Easy-to-Use Augmented Reality Neuronavigation Using a Wireless Tablet PC

Deng, W.; Li, F.; Wang, M.; Song, Z. (Shanghai)

Technical Note

25 Direct Targeting of the Thalamic Anteroventral Nucleus for Deep Brain Stimulation by $\mathrm{T}_{1}$-Weighted Magnetic Resonance Imaging at $3 \mathbf{T}$

Buentjen, L.; Kopitzki, K.; Schmitt, F.C.; Voges, J.;

Tempelmann, C.; Kaufmann, J.; Kanowski, M. (Magdeburg)

\section{Clinical Studies}

37 Stereotactic Neurosurgical Technique and Electrophysiological Study in Ablating the Ventromedial Shell of the Nucleus Accumbens

Yang, K.; Long, H.; Yuan, Y.; Qi, S.; Xu, B.; Wang, K.; Song, Y. (Guangzhou)

44 Use of an Artificial Neural Network for Diagnosis of Facial Pain Syndromes: An Update

McCartney, S.; Weltin, M.; Burchiel, K.J. (Portland, Oreg.)

53 Single-Institution Retrospective Series of Gamma Knife Radiosurgery in the Treatment of Multiple Sclerosis-Related Trigeminal Neuralgia: Factors that Predict Efficacy

Weller, M. (Cleveland, Ohio); Marshall, K.; Lovato, J.F.; Bourland, J.D.; deGuzman, A.F.; Munley, M.T.; Shaw, E.G.; Tatter, S.B.; Chan, M.D. (Winston-Salem, N.C.)

59 Frameless Stereotactic Functional Neuronavigation Combined with Intraoperative Magnetic Resonance Imaging as a Strategy in Highly Eloquent Located Tumors Causing Epilepsy

Sommer, B.; Grummich, P.; Hamer, H.; Bluemcke, I.; Coras, R.; Buchfelder, M.; Roessler, K. (Erlangen)
68 WSSFN Society News
69 ASSFN Society News
70 ESSFN The Mission

\section{Case Report}

31 Deep Brain Stimulation for Obsessive-Compulsive Disorder: Is the Side Relevant?

Barcia, J.A.; Reyes, L.; Arza, R.; Saceda, J.; Avecillas, J.; Yáñez, R.; García-Albea, J.; Ortiz, T.; López-Ibor, M.-I.; López-Ibor, J.-J. (Madrid) 